\title{
Bothriocephalus acheilognathi (Cestoda) in the endangered fish Profundulus hildebrandi (Cyprinodontiformes), Mexico
}

\author{
Ernesto Velázquez-Velázquez¹, David González-Solís² \& Guillermo Salgado-Maldonado 3 \\ 1. Universidad de Ciencias y Artes de Chiapas, Facultad de Ciencias Biológicas, Libramiento Norte Poniente 1150, Col. \\ Lajas Maciel, C.P. 29039, Tuxtla Gutiérrez, Chiapas, México; er_velazquez@yahoo.com \\ 2. El Colegio de la Frontera Sur, Unidad Chetumal, Av. Centenario Km. 5.5., C.P. 77900, Chetumal, Quintana Roo, \\ México; dgonzale@ecosur.mx \\ 3. Universidad Nacional Autónoma de México, Instituto de Biología, Apartado Postal 70153, 04510, México D.F. \\ México; gsalgado@ibiologia.unam.mx
}

Received 17-VIII-2010. C Corrected 13-I-2011. Accepted 15-II-2011.

\begin{abstract}
The Asian fish tapeworm, Bothriocephalus acheilognathi, has been considered one of the most dangerous parasites for cultured carp and a risk for native freshwater fish populations worldwide. This cestode is highly pathogenic for fishes especially fry. In this paper we record B. acheilognathi parasitizing the endangered and endemic freshwater fish Profundulus hildebrandi from the endorheic basin of San Cristóbal de las Casas, Chiapas, Mexico. B. acheilognathi was recorded from 10 of the 11 sampled localities, with high values of prevalence $(>60 \%)$ and mean abundance $(>4.50)$. The infection was persistent all through the year; gravid cestodes were recorded in all samples. It is assumed that $B$. acheilognathi entered to this area through the introduction of common carp Cyprinus carpio, for aquacultural purposes. The data presented in this paper document the successful introduction, colonization and establishment of this alien species into the endangered $P$. hildebrandi. Rev. Biol. Trop. 59 (3): 1099-1104. Epub 2011 September 01.
\end{abstract}

Key words: alien helminth, Bothriocephalus acheilognathi, endangered freshwater fish species, Profundulus hildebrandi, Mexico.

The Asian fish tapeworm, Bothriocephalus acheilognathi Yamaguti, 1934, has been considered one of the most dangerous pseudophyllidean cestodes for cultured carps in Europe (Heckmann et al. 1987), and a threat for native freshwater fish populations worldwide (Dove 1998). This cestode is highly pathogenic for fishes and has caused global concern. This cestode is the most successful freshwater fish parasite all throught the world. The species was originally described in Japan from the intestine of Acheilognathus rhombeus (Temminck \& Schlegal 1846) by Yamaguti (1934). Since that time, it has been introduced mostly along with Asiatic carps like Cyprinus carpio Linnaeus 1758, and Ctenopharyngodon idella (Valenciennes 1844), initially to East Europe and, thence to other parts of the world: North America (Heckmann et al. 1987), including Mexico (López-Jiménez 1981, Salgado-Maldonado \& Pineda-López 2003), and Australia (Dove \& Fletcher 2000), among others (Chubb 1981). The Asian fish tapeworm was introduced into Mexico through shipments of grass carp $C$. idella, brought from China for aquacultural purposes (López-Jiménez 1981).

Recently, Velázquez-Velázquez \& Schmitter-Soto (2004) reported Chiapas killifish Profundulus hildebrandi Miller 1950 specimens infected by tapeworms of the genus Bothriocephalus, probably B. acheilognathi. Profundulidae is one of the most primitive families within the order Cyprinodontiformes (pupfishes and allies); this lineage stems from the base 
of the genealogical tree of these freshwater euryhaline fishes (Parenti 1981). This family is also one of the least specious, with only eight described species. Profundulids tend to inhabit highland habitats in Southern Mexico and Central America. Within this profundulids, the most restricted species is the San Cristóbal killifish, $P$. hildebrandi, which is endemic to the San Cristóbal de las Casas basin, a small endorheic basin in Chiapas, Mexico. It's an endangered species according to the IUCN and Mexican red list (DOF 2002, Snoeks et al. 2007, Velázquez-Velázquez et al. 2009). Introduction of exotic organisms, along with habitat destruction are among the main threats for the conservation of endemic, endangered species like $P$. hildebrandi (Contreras-Balderas \& Escalante-Cavazos 1984).

This paper documents the first record of the Asian fish tapeworm in the endangered and endemic fish Profundulus hildebrandi, in the San Cristóbal de las Casas basin, Chiapas, Mexico.

\section{MATERIALS AND METHODS}

From February 2006 to February 2007 during the development of a research project about the biology and ecology of $P$. hildebrandi (Dominguez-Cisneros \& Velázquez-Velázquez et al. 2009), fish of this species were collected every two months. Eleven localities along the San Cristóbal de Las Casas river basin were sampled. This endorheic basin $\left(244 \mathrm{~km}^{2}\right)$, lies in the central highlands of the state of Chiapas, Mexico, at an altitude between 2110 to $2880 \mathrm{~m}$ above sea level (INEGI 1979) (Fig. 1). Immediately after caught, fish were fixed in $10 \%$ formalin; later, their intestines were examined for parasites using standard methods (VidalMartínez et al. 2001).

Recovered cestodes were counted, and sampled specimens were stained with Mayer's Paracarmine, dehydrated in a graded alcohol series, and mounted whole. In order to verify the presence of the Asian fish tapeworm in introduced carp, 19 C. carpio (standard length,

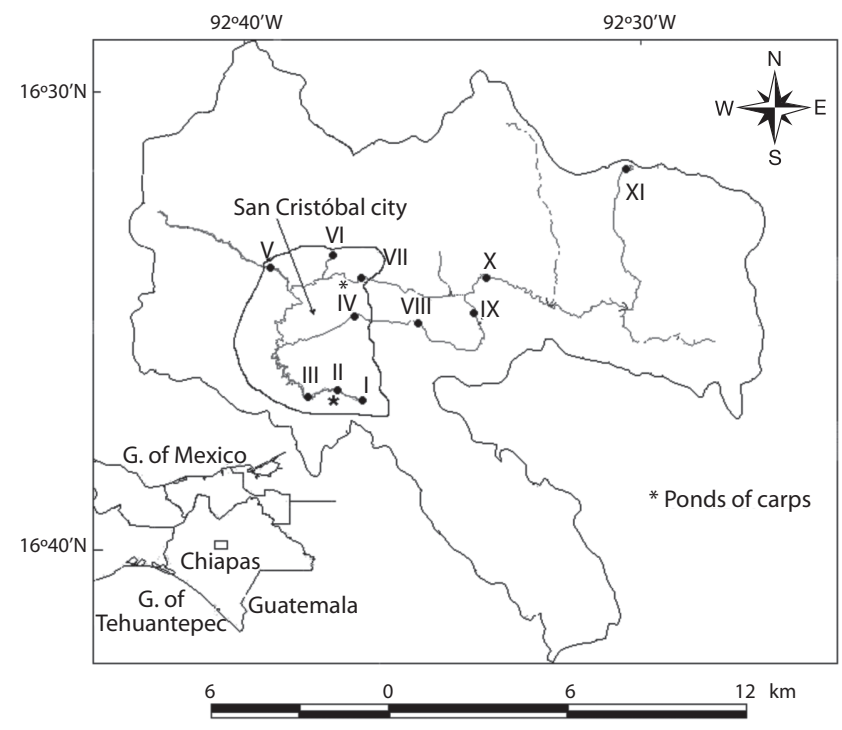

Fig. 1. Endorrheic basin of San Cristóbal de la Casas, Chiapas, Mexico showing localities (I-XI) where the endemic fish $P$. hildebrandi was collected. 
43-94mm) were also analyzed. All these carps were collected from la Albarrada (code II) (in March, July, October and December of 2006). Infection parameters, prevalence (percent of infection) and mean intensity (mean number of parasites per parasitized host) were calculated as proposed by Bush et al. (1997). Voucher specimens of fish hosts were deposited in the regional collection of fishes of the Universidad de Ciencias y Artes de Chiapas (MzUNICACH: 2433-2507). Voucher specimens of $B$ acheilognathi were deposited at Colección Nacional de Helmintos (CNHE: 7617), Instituto de Biología, Universidad Nacional Autónoma de México.

Infections parameters comparisons among sampling site and collection date were done by One-Way Analysis of Variance (ANOVA). Prior to ANOVA performance assessment of the assumptions of normality (KolmogorovSmirnov test) and homogeneity of variances (Cochran's test) were implemented (Sokal \& Rohlf 1998). Analyses were done using Statgraphics software (SGSC, 2000).

\section{RESULTS}

From February 2006 to February 2007, a total of 1310 Chiapas killifish $P$. hildebrandi (standard length: 9.66-117; mean 43.85;
$\mathrm{SD}=20.78$ ) was examined, 498 of which were parasitized by $B$. acheilognathi (prevalence $38 \%$ ). A total of 3093 individual tapeworms were recovered from the intestines of these fish. Data show $B$. acheilognathi is wide spread along the San Cristóbal de Las Casas basin, since it was recorded from all but one (arroyo Moxviquil, locality code VI) of the localities sampled.

Infection parameters varied significantly among localities, prevalence from $2 \%$ to $100 \%$ and mean intensity from 1 to 4.5 (prevalence $\mathrm{F}=33.79, \mathrm{p}<0.001$, mean intensity $\mathrm{F}=12.01$, $\mathrm{p}<0.001$ ) (Table 1). Highest levels of infection were recorded in three locations, two of which (codes II and VII) are situated in the high area of the basin, far from the third location (code $\mathrm{XI}$ ) which is situated at the Northern end of the basin (Fig. 1). The lowest values of infection were recorded from sites IV, VI, IX and $\mathrm{X}$. Infection parameters were not related to the number of hosts examined from each locality: number of fish examined Vs. prevalence $(\mathrm{r}=0.04)$ and Vs. mean intensity $(\mathrm{r}=0.323)$. Gravid specimens of $B$. acheilognathi were recovered from all locations.

The Asian fish tapeworm is present in the basin throughout the year, with high values of prevalence and mean intensity. These parameters were not significantly different between

TABLE 1

Infection parameters of Bothriocephalus acheilognathi in Profundulus hildebrandi from the San Cristóbal de Las Casas basin, Chiapas. Number of hosts examined (N), Prevalence (P) and mean intensity (I) (mean \pm SD)

\begin{tabular}{|c|c|c|c|c|c|}
\hline Locality, and codes & $\mathrm{N}$ & Infected & No. parasites & $\mathrm{P}(\%)$ & I \\
\hline I: Ecosur $\left(16^{\circ} 42^{\prime} 55^{\prime} \mathrm{N}-92^{\circ} 37^{\prime} 28^{\prime \prime} \mathrm{W}\right)$ & 234 & 127 & 588 & 54 & $4.62 \pm 2.38$ \\
\hline II: La Albarrada (1642’37’N - 92³7’32”W) & 168 & 102 & 1336 & 61 & $13.10 \pm 8.57$ \\
\hline III: 5 de Marzo (1642’34”N - 92³8’14”W) & 173 & 102 & 444 & 59 & $4.35 \pm 2.51$ \\
\hline IV: El Puente (1643'59’N - 92³6’54’W) & 85 & 2 & 2 & 2 & $1 \pm 0.00$ \\
\hline V: Arroyo Chamula (1644'52’N - 92³9’22’W) & 126 & 52 & 98 & 41 & $1.88 \pm 0.55$ \\
\hline 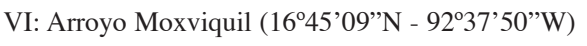 & 123 & 0 & 0 & 0 & 0.0 \\
\hline 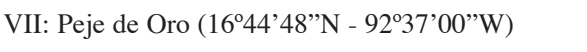 & 128 & 91 & 577 & 71 & $6.34 \pm 2.48$ \\
\hline VIII: El Arcotete (1645'57’N - 92³1'43”W) & 64 & 7 & 18 & 11 & $2.57 \pm 4.48$ \\
\hline IX: Arenal (1643’31”N - 92³4’53”W) & 64 & 4 & 4 & 6 & $1 \pm 0.00$ \\
\hline 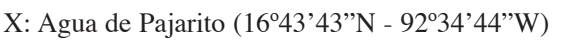 & 141 & 7 & 8 & 5 & $1.14 \pm 0.76$ \\
\hline XI: Laguna Soyul (1646’01’N - 92³1’39’W) & 4 & 4 & 18 & 100 & $4.50 \pm 4.04$ \\
\hline Total & 1310 & 498 & 3093 & 38 & 6.21 \\
\hline
\end{tabular}




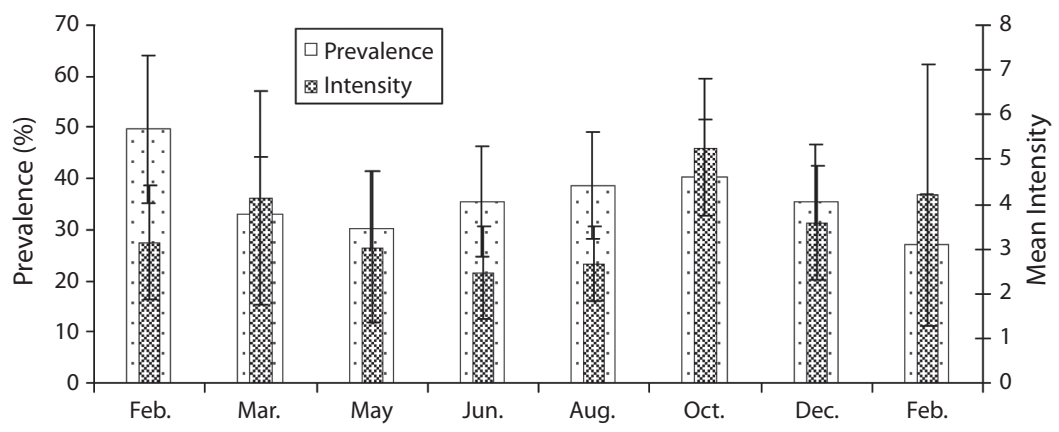

Fig. 2. Temporal variations in prevalence and mean intensity of Bothriocephalus acheilognathi in Profundulus hildebrandi from the San Cristóbal de las Casas, Chiapas basin. (bars $\pm 1 \mathrm{SE}$ ).

months (prevalence $\mathrm{F}=0.31, \mathrm{p}=0.945$, mean intensity $\mathrm{F}=0.37, \mathrm{p}=0.916$ ) (Fig. 2).

Regarding presence of the parasite in the introduced carp, two of the 19 C. carpio examined were infected with B. acheilognathi (prevalence $=10.52 \%$, mean intensity $=9$ ). Recorded in the Albarrada (code II), in the months of March and October.

\section{DISCUSSION}

The present paper document the parasitism of an alien helminth species, the Asian fish tapeworm, B. acheilognathi in an endemic and endangered fish $P$. hildebrandi along the natural geographical area of distribution of this freshwater fish species.

The data show B. acheilognathi parasitizing $P$. hildebrandi to be widespread throughout the entire San Cristóbal de Las Casas river basin, high prevalence and mean intensity levels were recorded in most sampled localities. The presence of the parasite was recorded all through the year. Mature, gravid tapeworms were recovered from most locations and from every sampling date.

All together these data suggest a successful introduction and establishment of this alien species into native fish $P$. hildebrandi populations in Chiapas. Noteworthy, high values of infection parameters, persistence throughout the year, and the recording of gravid specimens, point out the high transmission rates and successful population development of this tapeworm. Therefore, the data presented in this paper document the successful introduction, colonization and establishment of this alien species into the endangered $P$. hildebrandi.

The introduction of the Asian fish tapeworm into freshwater fishes of Mexico is well documented (López-Jiménez 1981, SalgadoMaldonado \& Pineda-López 2003, AguilarAguilar et al. 2010, Pérez-Ponce de León 2010). The spread of this parasite amongst freshwater fishes of Mexico is also well documented (Salgado-Maldonado 2006). It is assumed that the parasite entered into Chiapas through the introduction of common carp C. carpio since 1970 for aquaculture practices (R. Navarrete, pers. comm.). However, other exotic fish species, like the rainbow trout Oncorhynchus mykiss, and largemouth bass Micropterus salmoides have also been introduced to Chiapas. Such species were reported as susceptible to infection by B. acheilognathi (Salgado-Maldonado 2006) and might play an important role in transmission and spread of the parasite.

Bothriocephalus acheilognathi is notable among fish cestodes due to its broad host specificity. It has been recovered from more than 100 species of freshwater fish around the world (Salgado-Maldonado \& Pineda-López 2003). The parasite's lack of specificity at both definitive and intermediate hosts, the 
uncontrolled and indiscriminant translocation of cultured fishes, as well as its ability to colonize rapidly the new habitats had permitted to this cestode to spread successfully within the aquatic system. For example, in our area of study, the San Cristóbal Las Casas river basin, in localities II and VII, local government constructed aquaculture facilities for controlled carp production years ago. These rustic ponds are now in bad condition and infected carps had escaped and invaded those channels where $P$. hildebrandi inhabits, rendering possible the colonization and successful establishment of $B$. acheilognati in this new fish host. These localities showed the highest infection parameters in comparison to others.

Bothriocephalus acheilognathi is highly pathogenic to its hosts, causes serious damage and even death to fry and small fishes in high infections (Salgado-Maldonado et al. 1986, Salgado-Maldonado \& Pineda-López 2003). Due to their pathogenic effects the parasite is considered to be a serious threat to endemic fishes in Mexico (Salgado-Maldonado $\&$ Pineda-López 2003). The introduction of $B$. acheilognathi might have negative ecological impacts on native fishes in highlands of Chiapas. Moreover, the basins of the Grijalva and Usumacinta rivers in Chiapas contains more than 70 fish species (Miller 1986), including about $30 \%$ endemics, listed as species of conservation concern. The invasion of the San Cristóbal Las Casas river basin, undoubtedly facilitate the spread of $B$. acheilognathi to neighboring basins in Chiapas, Southern Mexico and Central America.

\section{ACKNOWLEDGMENTS}

This work was funded by a research grant from the Fondo Mixto Consejo Nacional de Ciencia y Tecnología/Gobierno del Estado de Chiapas (CHIS-2005-C03-072), under the collection permit No. SGPA/DGVS/04031/06 of the Dirección General de Vida Silvestre of the SEMARNAT, México. We thank Janeth Hernández Sánchez, Adán Gómez González, Víctor Villatoro Álvarez and Fabiola González
Velázquez for their collaboration during field and laboratory work. We are grateful for the comments of two anonymous referees who helped to improve the manuscript.

\section{RESUMEN}

El céstodo Asiático, Bothriocephalus acheilognathi, es considerado como uno de los helmintos más peligrosos para peces de cultivo, y un riesgo potencial para las poblaciones silvestres de peces en todo el mundo. La patología que causa es grave, principalmente en larvas y juveniles de peces. En este trabajo registramos la presencia de $B$. acheilognathi en el pez endémico de Chiapas y amenazado de extinción, Profundulus hildebrandi, en la cuenca endorreica de San Cristóbal de Las Casas, Chiapas, México. El céstodo $B$. acheilognathi fue registrado en 10 de las 11 localidades muestreadas, con valores altos de prevalencia $(>60 \%)$ e intensidad promedio ( $>4.50)$. Registramos esta infección durante todo el año, con presencia de céstodos grávidos en todos los meses muestreados. Asumimos que $B$. acheilognathi ingresó a esta área geográfica con la introducción de la carpa común, Cyprinus carpio, para acuicultura. Los datos que presentamos en este trabajo documentan la introducción exitosa, la colonización y el establecimiento de esta especie exótica de parásito sobre $P$. hildebrandi, especie dulceacuícola, endémica y amenazada de extinción.

Palabras clave: parásitos introducidos, Bothriocephalus acheilognathi, pez dulceacuícola endémico, Profundulus hildebrandi, México.

\section{REFERENCES}

Aguilar-Aguilar, G., A. José-Abrego \& G. Pérez-Ponce de León. 2010. Cestoda, Bothriocephalidae, Bothriocephalus acheilognathi Yamaguti, 1934; Nematoda, Rhabdochonidae, Rhabdochona canadensis Moravec and Arai, 1971: New records for the state of Puebla, Mexico, and a new fish host. Check List 6: 437-438.

Bush, A.O., K.D. Lafferty, J.M. Lotz \& A. Shostak. 1997. Parasitology meets ecology on its own terms: Margolis et al. revisited. J. Parasitol. 83: 575-583.

Chubb, J.C. 1981. The Chinese tapeworm Bothriocephalus acheilognathi Yamaguti, 1934 (synonym B. gowkongensis Yeh, 1955) in Britain. Proc. Sec. British Freshwater Fish. Conf. 40-41.

Contreras-Balderas, S. \& M. Escalante-Cavazos. 1984. Distribution and know impacts of exotic fishes in Mexico, p. 102-130. In W. Courtenay \& J. Stauffer (eds.). Distribution, biology and management of 
exotic fishes. The Johns Hopkins University, Baltimore. USA.

DOF (Diario Oficial de la Federación). 2002. Norma Oficial Mexicana Nom-059-ECOL-2001, Protección ambiental-especies nativas de México de flora y fauna silvestres-categorías de riesgo y especificaciones para su inclusión, exclusión o cambio-lista de especies en riesgo. Secretaria de Medio Ambiente y Recursos Naturales.

Domínguez-Cisneros, S. \& E. Velázquez-Velázquez. 2009. Abundancia, distribución y aspectos de la biología reproductiva y alimenticia de Profundulus hildebrandi, pez endémico de San Cristóbal de las Casas, Chiapas. Universidad de Ciencias y Artes de Chiapas. Informe final FOMIX/CHIAPAS proyecto No. Chis2005-C03-072, Mérida, Yucatán, México.

Dove, A.D. 1998. A silent tragedy: parasites and the exotic fishes of Australia. Proc. R. Soc. Queensl. 107: 109-113.

Dove, A.D. \& A. Flecther. 2000. The distribution of the introduced tapeworm Bothriocephalus acheilognathi in Australian freshwater fishes. J. Helminthol. 74: 121-127.

Heckmann, R.A., P.D. Greger \& J.E. Deacon. 1987. New host records for the Asian fish tape worm, Bothriocephalus acheilognathi, in endangered fish species from the Virgin River, Utah, Nevada and Arizona. J. Parasitol. 73: 226-227.

INEGI (Instituto Nacional de Estadística, Geografía e Informática). 1979. Cartas temáticas de aguas superficiales y subterráneas, Uso de Suelo y vegetación, México.

López-Jiménez, S. 1981. Cestodos de peces I. Bothriocephalus (Clestobothrium) acheilognathi (Cestoda: Bothriocephalidae). An. Inst. Biol., Univ. Nac. Auton. Mex., Ser. Zool. 51: 69-84.

Miller, R.R. 1986. Composition and derivation of the freshwater fish fauna of Mexico. An. Esc. Nac. Cienc. Biol. (Mexico City) 30: 121-153.

Parenti, L.R. 1981. A phylogenetic and biogeographic analysis of cyprinodontiform fishes (Teleostei, Atherinomorpha). Bull. Am. Mus. Nat. Hist. 168: 335-557.
Pérez-Ponce de León, G., R. Rosas-Valdez, R. AguilarAguilar, B. Mendoza-Garfias, C. Mendoza-Palmero, L. García-Prieto, A. Rojas-Sánchez, R. Briosio-Aguilar, R. Pérez-Rodríguez \& O. Domínguez- Domínguez. 2010. Helminth parasites of freshwater fishes, Nazas River basin, Northern Mexico. Check List 6: 26-35.

Salgado-Maldonado, G. 2006. Checklist of helminth parasites of freshwater fishes from Mexico. Zootaxa 1324: 1-357.

Salgado-Maldonado, G., S. Guillén-Hernández \& D. Osorio-Sarabia. 1986. Presencia de Bothriocephalus acheilognathi Yamaguti, 1934 (Cestoda: Bothriocephalidae) en peces de Pátzcuaro, Michoacán, México. An. Inst. Biol., Univ. Nac. Auton. Mex., Ser. Zool. 57: 213-218.

Salgado-Maldonado, G. \& R. Pineda-López. 2003. The Asian fish tapeworm Bothriocephalus acheilognathi: a potential threat to native freshwater fish species en Mexico. Biol. Invasions 5: 261-268.

Snoeks, J., P. Laleye \& T. MacBeath. 2007. Profundulus hildebrandi. IUCN Red List of Threatened Species, Version 2010.1. (Available: www.iucnredlist.org).

Sokal, R.R. \& F. Rolf. 1998. Biometry: The principles and practice of statistic in biological research. Freeman, New York, USA.

SGSC. 2000: Statgraphics version 5.1. Statistical Graphics System Corporation, Rockville, Maryland, USA.

Velázquez-Velázquez, E. \& J.J. Schmitter-Soto. 2004. Conservation status of Profundulus hildebrandi Miller (Teleostei: Profundulidae) in the face of urban growth in Chiapas, Mexico. Aquat. Conserv. 14: 201-209.

Velázquez-Velázquez, E., J. Schmitter-Soto \& S. Domínguez-Cisneros. 2009. Threatened fishes of the world: Profundulus hildebrandi Miller, 1950 (Profundulidae). Environ. Biol. Fish. 84: 345-346.

Vidal-Martínez, V.M., M.L. Aguirre-Macedo, T. Scholz, D. González-Solís \& E.F. Mendoza-Franco. 2001. Atlas of the helminth parasites of cichlid fish of Mexico. Academia, Praga, Czech Republic.

Yamaguti, S. 1934. Studies on the helminth fauna of Japan. Part 4. Cestodes of fishes. Jpn. J. Zool. 6: 1-112. 